\title{
Campylobacter isolation from the feces of sheep with a history of reproductive disorders bred in the state of São Paulo, Brazil
}

\section{Isolamento de Campylobacter em fezes de ovinos com distúrbios reprodutivos pertencentes a criatórios do Estado de São Paulo, Brasil}

\author{
Huber Rizzo $^{1 *}$; Lilian Gregory ${ }^{2}$; Fidel Beraldi ${ }^{3}$; Aline Feola de Carvalho ${ }^{4}$; \\ Eliana Scarcelli Pinheiro ${ }^{5}$
}

\begin{abstract}
Campylobacter species are a significant cause of sheep abortion in most sheep-raising countries. The relationship between the presence of Campylobacter spp. in fecal samples and reproductive disorders was investigated in 274 sheep from 28 properties in the state of São Paulo, Brazil. Biological samples from 16 aborted fetuses, one uterus, six placentas, five uterine secretion samples, five vaginal swabs, 17 semen samples, and three preputial swabs were also subjected to bacterial isolation. The bacteria were isolated from fecal samples of $14.9 \%(5 / 28)$ of the properties, affecting $3.65 \%(10 / 274)$ of the sheep, 3.5\% (9/255) of females and 5.3\% (1/19) of males. Campylobacter jejuni was the most prevalent species, present in $66.67 \%$ (7) of the positive samples, followed by Campylobacter coli, present in $22.22 \%$ (2), and one strain was identified as Campylobacter spp. The birth of "weak" lambs ( $\mathrm{p}=0.06$, $\mathrm{OR}=6.83$ and $\mathrm{CI}=1.73$ to 27.05 ) and neonatal death ( $\mathrm{p}=0.087, \mathrm{OR}=3.5$ and $\mathrm{CI}=0.83$ to 14.72 ) were associated with the fecal isolation of Campylobacter spp. Diarrhea was also associated with the bacteria $(\mathrm{p}=0.003, \mathrm{OR}=9.83$ and $\mathrm{CI}=2.19$ to 44.18$)$. The dissemination of Campylobacter $\mathrm{spp}$. in Brazilian sheep is low and that, at present, the existing strains are not responsible for significant economic losses in sheep production, especially in adult animals.
\end{abstract}

Key words: Campylobacteriosis, Campylobacter jejuni, Campylobacter coli, and neonatal death

\section{Resumo}

Espécies de Campylobacter são uma importânte causa de abortos em ovinos de muitos paíse. No intuito do isolamento de Campylobacter spp. em ovinos, foram colhidas 274 amostras fecais de ovinos do Estado de São Paulo, Brasil que possuiam histórico de distúrbios reprodutivos. O isolamento bacteriano ocorreu em 3,65\% (10/274) das amostras, correspondendo 3,5\% (9/255) das fêmeas e 5,3\% (19/01) dos machos. Campylobacter jejuni foi a mais prevalente, responsável por $66,67 \%$ (7) das amostras positivas

\footnotetext{
${ }^{1}$ Prof., Dept ${ }^{\circ}$ de Medicina Veterinária, Universidade Federal Rural de Pernambuco, DMV/UFRPE, Recife, PE, Brasil. E-mail: hubervet@gmail.com

${ }^{2}$ Prof $^{a}$, Dept ${ }^{\circ}$ de Clínica Médica, Faculdade de Medicina Veterinária e Zootecnia, Universidade de São Paulo, VCM/FMVZ/USP, São Paulo, SP, Brasil. E-mail:lgregory@usp.br

3 Discente do Programa de Pós-graduação em Ciências da Computação, Instituto de Matemática, Universidade de São Paulo, IME/ USP, São Paulo, Brasil. E-mail: fidelberaldi@yahoo.com.br

${ }^{4}$ Pesquisadora do Laboratório Central - Bacteriologia do Instituto Adolfo Lutz, IAL, São Paulo, SP, Brasil. E-mail: linebio@ gmail.com

5 Pesquisadora do Laboratório de Doenças Bacterianas da Reprodução do Instituto Biológico, IB, São Paulo, SP, Brasil. E-mail: pinheiro@biologico.sp.gov.br

* Author for correspondence
} 
e o Campylobacter coli responsáveis por 22,22\% (2) e uma cepa foi identificada como Campylobacter spp. Os parâmetros analisados que apresentaram valor de $\mathrm{p}<0,1$ foram o nascimento de cordeiros "fracos" ( $\mathrm{p}=0,06, \mathrm{OR}=6,83$ e IC=1,73 a 27,05) e morte neonatal $(\mathrm{p}=0,087, \mathrm{OR}=3,5$ e $\mathrm{IC}=0,83$ a 14,72$)$. Foi observado que os animais infectados apresentam maior risco de quadros de diarreia $(\mathrm{p}=0,003$, $\mathrm{OR}=9,83$ e IC=2,19 a 44,18). Campylobacter jejuni e Campylobacter coli estão presentes nos rebanhos paulistas e observou-se associação de ovinos com isolamento bacteriano fecal com quadro de nascimento de cordeiros "fracos" e consequente morte neonatal. Além de sua associação com quadros de diarreia que predispões à infecção oral de cordeiros a bactéria. A disseminação de Campylobacter spp. nos rebanhos ovinos Brasileiros é baixa e que, por enquanto, as cepas existentes não são responsáveis por grandes prejuízos na ovinocultura, principalmente em animais adultos.

Palavras-chave: Campilobacterioses, Campylobacter jejuni, Campylobacter coli e morte neonatal

\section{Introduction}

Campylobacter jejuni, Campylobacter coli and Campylobacter fetus subspecies fetus are present worldwide and are the main species of Campylobacter that cause reproductive disorders in sheep (HEDSTROM et al., 1987; DIKER et al., 1988; SAHIN et al., 2008). These bacteria can be found in environments such as soil, water and food, most likely as result of contact with contaminant sources such as animal feces and aborted tissues (BROMAN et al., 2002; PITKÄNEN, 2013). May colonize several animal species with the risk of interspecies transmission. Roug et al. (2013) isolated C. jejuni and C. coli in sheep, goats, cattle and pigs at agriculture fairs in California, USA. Pao et al. (2014) found that sheep pose a greater risk than goats in $C$. jejuni contamination at co-grazing small ruminant farms.

Healthy sheep can act as reservoirs of these bacteria (AÇIK; ÇETINKAYA, 2006; SPROSTON et al., 2010), intermittently excreting them in the pasture, especially in response to stressful situations such as birth, weaning and feeding changes (STANLEY et al., 1998; JONES et al., 1999), however are rapidly inactivated on grassland in the occurrence of high temperatures (MORIARTY et al., 2011). As similar strains are capable of causing abortions in poultry and cattle, these animals are also considered reservoirs of Campylobacter spp. (DIKER et al., 2000). The presence of birds on sheep farms increases the risk of lambs becoming infected in their first days of life (BROMAN et al.,
2002; PAO et al., 2014).

Scarcelli et al. (1998) studied the feces of healthy sheep in the state of São Paulo and obtained Campylobacter jejuni isolates in 2.9\% (2/69) of sheep. In Nigeria was obtained 18\% (93/518) of Campylobacter isolates from rectal swab in ovine. The Campylobacter species isolated in this study were Campylobacter jejuni (79,6\%), Campylobacter coli (11,8\%), Campylobacter lari $(6,4 \%)$ and Campylobacter upsaliensis (2,2\%) (SALIHU et al., 2009).

In Brazil, the occurrence of these bacteria and their association with reproductive problems in sheep is low. While Campylobacter jejuni and Campylobacter fetus subspecies fetus have been isolated in cases of abortions in Brazil (VARGAS et al., 2005; GRESSLER et al., 2012), these bacteria represent a major cause of abortions in countries like New Zealand with high rates of fetal isolates (BIRD et al., 1984; QUINLIVAN; JOOP, 1982). Even vaccinated animals may have reproductive problems because the bacterium exhibits high variability within the herd, and the immunization is not effective against all strains capable of causing abortions (COLLINS; LISLE, 1984; DELONG et al., 1996; FENWICK et al., 2000).

Campylobacteriosis in sheep are characterized by abortion in the last trimester of gestation, stillbirth, the birth of premature and weak lambs, and occasionally the death of ewes due to metritis (DENNIS, 1975; HEDSTROM et al., 1987; 
SAHIN et al., 2008; GRESSLER et al., 2012) and of lambs due to diarrhea and/or gastroenteritis (STANSFIELD et al., 1986). Many sheep have diarrhea before the first episode of abortion, and diarrhea occurs in approximately $10 \%$ of the herd (WALT, 1994). Further, occasionally retention of dead fetus is observed which may lead to death of the pregnant ewes due to septicemia and uterine sepsis. However, no clinical signs can be seen in these ewes at the beginning of infection (SKIRROW, 1994).

Artificially inoculated females aborted in $100 \%$ of cases, with clinical signs similar to cases of natural infection, characterized by purulent endometritis and necropurulent placentitis with yellow cotyledons and edematous caruncles with hemorrhagic streaks, covered by mucoid-serosanguinous and fibrinous exudate (HEDSTROM et al., 1987). C. coli, in Turkey, was isolated and identified from vaginal discharge samples of two sheep and 10,25\% of aborted foetus (BÜYÜK et al., 2011). Zan Bar et al. (2008) experimentally inoculated males with Campylobacter fetus fetus, observing decreased motility and sperm vigor along with morphological changes, suggesting that this species may be toxic to sperm cells.

Due to the potential of Campylobacter spp. to cause reproductive disorders in sheep, the present study aimed to investigate the relationship between reproductive disorders and fecal isolates of these bacteria in sheep from the state of São Paulo.

\section{Materials and Methods}

Between the years 2008 and 2009 a total of 274 fecal samples were collected from sheep with a history of reproductive disorders; 255 were collected from females and 19 from males. The animals were from 28 farms located in 19 municipalities of the state of São Paulo, Brazil being them Atibaia, Campinas, Cunha, Indaiatuba, Itapevi, Itatiba, Itu, Itupeva, Jundiaí, Morungaba, Pedra Bela, Piedade, Piracaia, Pirassununga, Santa Rita do Passa Quatro,
Santo Anastácio, São Paulo, Sorocaba, Valinhos and Vargem. In addition to the fecal samples, 16 aborted fetuses, one uterus, six placentas, five samples of uterine secretions, five vaginal swabs, 17 semen samples and three preputial swabs were subjected to bacterial isolation of Campylobacter spp. All samples were placed in sterile plastic bottles and refrigerated until the time of diagnosis, which occurred within 24 hours after collection.

The bacterial isolation from fecal samples was performed according to Scarcelli et al. (1998). Bacterial isolation from the semen samples was performed according to the method described by Genovez et al. (1999), and the other samples were processed according to Scarcelli et al. (2004).

The reproductive disorders observed in this study were abortion, endometritis, fetal malformation, birth of "weak" lambs, stillbirth, dystocia, premature delivery, the presence of uterine secretions, uterine prolapse, repeat estrus, infertility and/or placental retention in ewes and infertility, orchitis, epididymitis, degeneration, testicular hyperplasia or hypoplasia and/or lack of libido in rams.

All sheep in the present study underwent clinical and gynecological or andrological examination (GRUNERT et al., 2005), and the observed alterations were recorded in individual clinical records. Among the observations in females were hyperpigmented or hypopigmented vaginal mucosa; the presence of nodules, petechiae, pustules, telangiectasias and vesicles in the vaginal region; and the presence of uterine secretions. Males were diagnosed with orchitis, epididymitis and infertility.

The results were analyzed using a multidimensional descriptive technique that analyzed the proportion and number of individuals with each group of disease variables. The groups with significant relationships $(\mathrm{p}<0.1)$ were evaluated using logistic regression to measure the risk associated with the various model variables (AGRESTI, 2012; PAULINO; SINGER, 2006). 


\section{Results}

The percentage of fecal samples positive for Campylobacter spp. was 3.65\% (10/274); 3.5\% $(9 / 255)$ of the samples from females and $5.3 \%$ $(1 / 19)$ of the samples from males. The isolates were obtained from five different herds (5/28), with four samples obtained from one herd, three from a second and only one sample from the remaining farms.

Two species were identified, with Campylobacter jejuni as the most prevalent, present in $66.67 \%$ (7/10) of the isolates, followed by Campylobacter coli, present in $22.22 \%(2 / 10)$. It was not possible to identify the species of the final sample, and it was instead classified by genus-specific tests as Campylobacter spp.
Campylobacter jejuni was isolated from the Santa Inês rams. This ram was housed in an individual stall, where its walls and troughs were contaminated with feces from birds that were raised free on the property. No bacteria were isolated from any of the other biological samples subjected to diagnosis.

No relationship was found between the bacterial isolation and the presence of symptoms at the time of gynecological or andrological examination. Referring to the history of reproductive disorders, a significant correlation was observed between the presence of Campylobacter spp. and the birth of "weak" lambs, neonatal death and placental retention (Table 1).

Table 1. Analysis of significance ( $\mathrm{p}$ value) between ewes positive for fecal isolation of Campylobacter spp. and the presence of reproductive disorders.

\begin{tabular}{|c|c|c|c|c|c|}
\hline Variables & & $\mathrm{N}$ & Isolations [n] (\%)] & Odds ratio $(\mathrm{CI})(95 \%)$ & $\mathrm{p}$ Value \\
\hline \multirow[t]{2}{*}{ Abortion } & Yes & 136 & $5(3.7 \%)$ & - & 0.87 \\
\hline & No & 119 & $4(3.4 \%)$ & & \\
\hline \multirow[t]{2}{*}{ Endometritis } & Yes & 6 & $0(0.0 \%)$ & - & - \\
\hline & No & 249 & $9(3.6 \%)$ & & \\
\hline \multirow[t]{2}{*}{ Fetal malformation } & Yes & 2 & $0(0.0 \%)$ & - & - \\
\hline & No & 253 & $6(2.7 \%)$ & & \\
\hline \multirow[t]{2}{*}{ Neonatal death } & Yes & 33 & $3(9.1 \%)$ & $3.5(0.83-14.72)$ & 0.087 \\
\hline & No & 222 & $6(2.7 \%)$ & & \\
\hline \multirow[t]{2}{*}{ Birth of weak lamb } & Yes & 29 & $4(13.8 \%)$ & $6.83(1.73-27.05)$ & 0.006 \\
\hline & No & 226 & $5(2.2 \%)$ & & \\
\hline \multirow[t]{2}{*}{ Stillbirth } & Yes & 7 & $0(0.0 \%)$ & - & - \\
\hline & No & 248 & $9(3.6 \%)$ & & \\
\hline \multirow[t]{2}{*}{ Dystocia } & Yes & 6 & $1(16.7 \%)$ & - & 0.12 \\
\hline & No & 249 & $8(3.2 \%)$ & & \\
\hline \multirow[t]{2}{*}{ Premature delivery } & Yes & 3 & $0(0.0 \%)$ & - & - \\
\hline & No & 252 & $9(3.6 \%)$ & & \\
\hline \multirow[t]{2}{*}{ Uterine prolapse } & Yes & 2 & $0(0.0 \%)$ & - & - \\
\hline & No & 253 & $9(3.6 \%)$ & & \\
\hline \multirow[t]{2}{*}{ Repeat estrus } & Yes & 77 & $0(0.0 \%)$ & - & - \\
\hline & No & 178 & $9(5.1 \%)$ & & \\
\hline \multirow[t]{2}{*}{ Placental retention } & Yes & 3 & $1(33.3 \%)$ & $15.88(1.26-187.61)$ & 0.032 \\
\hline & No & 252 & $8(3.2 \%)$ & & \\
\hline
\end{tabular}

Ref.: Reference parameter for the analysis of significance. Values of $\mathrm{p} \leq 0.1$ indicate statistical significance. 
Among the signs observed during the clinical examination, a significant relationship was also observed between animals with diarrhea and isolates of Campylobacter spp. $(\mathrm{p}=0.003)$, with a risk factor of 9.83 (2.19-44.18).

\section{Discussion}

Among the three species of Campylobacter capable of causing reproductive disorders in sheep, Campylobacter jejuni, Campylobacter coli and Campylobacter fetus fetus (HEDSTROM et al., 1987; DIKER et al., 1988; SAHIN et al., 2008; BÜYÜK et al., 2011), only the latter was not isolated in this study of the herds of São Paulo. However, the same species were also isolated in previous studies in healthy animals (STANLEY et al., 1998; JONES et al., 1999). Both species were isolated in sheep, goats and cattle healthy in USA (ROUG et al., 2013). Should be borne attention because the C. coli and C. jejuni isolates in this study have a zoonotic character, and are associated with acute gastrointestinal disease and septicemia in humans (STEPHEN, 2013).

The percentages of isolates $(3.65 \%)$ observed in the present study were similar to those obtained in Brazil by Scarcelli et al. (1998), but lower than those in the studies conducted mainly in New Zealand, United States and Nigeria, where the bacteria has a greater epidemiological impact (QUINLIVAN; JOOP, 1982; BIRD et al., 1984; MANNERING et al., 2004, 2006; SALIHU et al., 2009). Between 2006 and 2009, in New Zealand, sera were tested for C. fetus fetus, 1,644/3,429 (48\%) were positive, only $34 / 298$ (11\%) flocks tested for were completely seronegative (DEMPSTER et al., 2011)

Birds were observed at 7/28 properties, and although the presence of birds is an aggravating factor for infection by Campylobacter spp. (BROMAN et al., 2002; PAO et al., 2014), a significant relationship with the disease was not observed in this study. However, the Campylobacter jejuni infection of the Santa Inês ram likely occurred orally because its stall was heavily contaminated with the feces of birds that roamed free. The ram had a history of low fertility after the breeding season, which may have been influenced by the bacterial toxicity of sperm cells (ZAN BAR et al., 2008), but the bacteria could not be isolated from the semen samples from this ram.

Regarding the history of reproductive disorders, the results corroborate those of other authors associating the infection with the birth of "weak" lambs and subsequent neonatal death (DENNIS, 1975). However, no association was observed between infection and abortion, presenting a different picture from that reported in countries like New Zealand (QUINLIVAN; JOOP, 1982; BIRD et al., 1984; MANNERING et al., 2006), where prophylactic measures such as vaccination have been observed to decrease cases of miscarriage (BIRD et al., 1984; FENWICK et al., 2000; MANNERING et al., 2004). This measure has not yet been adopted in Brazilian herds because abortions occur sporadically in sheep (VARGAS et al., 2005; GRESSLER et al., 2012). In United States, was discovered the highly virulent $C$. jejune clone (clone SA, for sheep abortion) as the predominant cause of Campylobacter-associated abortion in sheep, all isolates were resistant to tetracycline, is quite intriguing and suggests that the clone is ecologically well adapted and pathologically hypervirulent in ruminants (SAHIN et al., 2008).

This difference between the association of clinical signs may occur due to the variability of strains of Campylobacter jejuni and Campylobacter coli (COLLINS; LISLE, 1984; DELONG et al., 1996) or due to the inability to isolate Campylobacter fetus fetus from the 255 fecal samples from ewes with reproductive disorders, given that Campylobacter fetus fetus is frequently associated with abortion (DENNIS, 1975; BIRD et al., 1984; COLLINS; LISLE, 1984; KIRKBRIDE, 1993; DELONG et al., 1996; FENWICK et al., 2000; MANNERING et al., 2004; AGERHOLM et al., 2006; SAHIN et al., 2008). Another characteristic of the isolated 
species is that they can be found in both healthy animals (STANLEY et al., 1998; JONES et al., 1999; AÇIK; ÇETINKAY, 2006; OPORTO et al., 2007; SPROSTON et al., 2010) and animals with reproductive disorders (DELONG et al., 1996; VARGAS et al., 2005; SAHIN et al., 2008).

In the case of placental retention $(\mathrm{p}=0.032$ and a risk factor of 15.36), no association was observed with infection as in other studies; however, of the three animals that had placental retention, one was positive for Campylobacter spp.

Among the clinical signs observed during the clinical exam, a significant relationship was observed between animals with diarrhea and isolates of Campylobacter spp. $(\mathrm{p}=0.003)$ with a risk factor of 9.83, in agreement with Walt (1994) who reported cases of diarrhea before episodes of abortion. However, among the three females with diarrhea who were positive for Campylobacter spp., only one had a history of abortion, and the other two gave birth to "weak" lambs that may have been contaminated immediately after delivery.

\section{Conclusion}

Note that the dissemination of Campylobacter spp. in Brazilian sheep is low and that, at present, the existing strains are not responsible for significant economic losses in sheep production, especially in adult animals. However, there is a risk that these bacteria can lead to the birth of "weak" lambs and subsequent neonatal death, and of the spread of bacteria in the herd through cases of diarrhea, especially during periods in which animals are under stress, predisposing lambs to fecal-oral infection and compromising their development.

\section{References}

AÇIK, M. N.; ÇETINKAYA, B. Heterogeneity of Campylobacter jejuni and Campylobacter coli strains from healthy sheep. Veterinary Microbiology, Amsterdam, v. 115, n. 4, p. 370-375, 2006.
AGERHOLM, J. S.; AALBAEK, B.; FOG-LARSEN, A. M.; BOYE, M.; HOLM, E.; JENSEN, T. K.; LINDHARDT, T.; LARSEN, L. E.; BUXTON, D. Veterinary and medical aspects of abortion in Danish sheep. Acta Pathologica Microbiologica et Immunologica Scandinavica, Copenhagen, v. 114, n. 2, p. 146, 2006.

AGRESTI, A. Categorical data analysis. 3. ed. New York: Wiley-Interscience, 2012. 744 p.

BIRD, M. M. E.; STEPHENS, D. J.; WALL, E. P.; DE LISLE, G. W. Serology of Campylobacter fetus fetus strains from four outbreaks of ovine abortion. New Zealand Veterinary Journal, Wellington, v. 32, n. 1-2, p. 14-17, 1984

BROMAN, T.; PALMGREN, H.; BERGSTROM, S.; SELLIN, M.; WALDENSTRÖM, J.; DANIELSSONTHAM, M. L.; OLSEN, B. Campylobacter jejuni in black-headed gulls (Larus ridibundus): prevalence, genotypes, and influence on $C$. jejuni epidemiology. Journal of Clinical Microbiology, Washington, v. 40, n. 12, p. 4594-4602, 2002.

BÜYÜK, F.; CELEBİ, Ö.; SAHIN, M.; ÜNVER, A.; TAZEGÜL, E. Brucella and Campylobacter mixed infection in two different sheep and goat herds. Kafkas Üniversitesi Veteriner Fakültesi Dergisi, Kars, v. 17, p. 177-180, 2011. Supplement A.

COLLINS, D. M.; LISLE, G. W. Typing of Campylobacter fetus fetus isolated from sheep abortions in New Zealand. New Zealand Veterinary Journal, Wellington, v. 33, n. 4, p. 52-53, 1984.

DIKER, K. S.; ESENDAL, O. M.; AKAN, M. Epidemiology of ovine Campylobacter infection determined by numerical analysis of electrophoretic protein profiles. Journal of Veterinary Medicine Series B, Berlin, v. 47, n. 10, p. 739-743, 2000.

DIKER, K. S.; SAHAL, M.; AYDIN, N. Ovine abortion associated with Campylobacter coli. Veterinary Record, London, v. 122, n. 4, p. 87, 1988.

DELONG, W. J.; JAWORSKI, M. D.; WARD, A. C. S. Antigenic and restriction enzyme analysis of Campylobacter spp associated with abortion in sheep. American Journal of Veterinary Research, Chicago, v. 57, n. 2, p. 163-167, 1996.

DENNIS, S. M. Perinatal lamb mortality in Western Australia: 5. Vibrionic infection. Australian Veterinary Journal, Victoria, v. 51, n. 1, p. 11-13, 1975.

DEMPSTER, R. P.; WILKINS, M.; GREEN, R. S.; LISLE, G. W. Serological survey of Toxoplasma gondii and Campylobacter fetus fetus in sheep from New Zealand. New Zealand Veterinary Journal, Wellington, v. 59, n. 4, p. 155-159, 2011. 
FENWICK, S. G.; WEST, D. M.; HUNTER, J. E. B.; SARGISON, N. D.; AHMED, F.; LUMSDEN, J. S.; COLLETT, M. G. Campylobacter fetus fetus abortions in vaccinated ewes. New Zealand Veterinary Journal, Wellington, v. 48, n. 5, p. 155-157, 2000.

GENOVEZ, M. E.; SCARCELLI E.; FACIOLLI, M. R.; CARDOSO, M. V.; TEIXEIRA, S. R. Avaliação bacteriológica de sêmen "in natura" e industrializado de touros. Revista Brasileira de Reprodução Animal, Belo Horizonte, v. 23, n. 3, p. 403-405, 1999.

GRESSLER, L. T.; KIRINUS, J. K.; MACHADO, G.; PRESTES, D. S.; VARGAS, A. C. Campylobacter fetus subespécie fetus: abortamento e natimortalidade em ovinos. Ciência Rural, Santa Maria, v. 42, n. 4, p. 697700, 2012.

GRUNERT, E.; BRIGEL. E. H.; VALE, W. G.; BRIGEL JUNIOR, E. H. Patologia e clínica da reprodução dos animais mamíferos: ginecologia. São Paulo: Varela, 2005. $551 \mathrm{p}$.

HEDSTROM, O. R.; SONN, R. J.; LASSEN, E. D.; HULTGREN, B. D.; CRISMAN, R. O.; SMITH, B. B.; SNYDER, S. P. Pathology of Campylobacter jejuni abortion in sheep. Veterinary Pathology, Basel, v. 24, n. 5, p. 419-426, 1987.

JONES, K.; HOWARD, S.; WALLACE, J. S. Intermittent shedding of thermophilic campylobacters by sheep at pasture. Journal of Applied Microbiology, Oxford, v. 86, n. 3, p. 531-536, 1999.

KIRKBRIDE, C. A. Diagnoses in 1,784 ovine abortions and stillbirths. Journal of Veterinary Diagnostic Investigation, Columbia, v. 5, n. 3, p. 398-402, 1993.

MANNERING, S. A.; WEST, D. M.; FENWICK, S. G.; MARCHANT, R. M.; O'CONNELL, K. Pulsed-field gel electrophoresis of Campylobacter jejuni sheep abortion isolates. Veterinary Microbiology, Amsterdam, v. 115, n. 1-3, p. 237-242, 2006.

MANNERING, S. A.; WEST, D. M.; FENWICK, S. G.; MARCHANT, R. M.; PERKINS, N. R.; O'CONNELL, K. Pulsed-field gel electrophoresis typing of Campylobacter fetus subspecies fetus isolated from sheep abortions in New Zealand. New Zealand Veterinary Journal, Wellington, v. 52, n. 6, p. 358-363, 2004.

MORIARTY, E. M.; MACKENZIE, M. L.; KARKI, N.; SINTON, L. W. Survival of Escherichia coli, Enterococci, and Campylobacter spp. In Sheep Feces on Pastures. Applied and Environmental Microbiology, Washingnton, v. 77, n. 5, p. 1797-1803, 2011.

OPORTO, B.; ESTEBAN, J. I.; ADURIZ, G.; JUSTE, R. A.; HURTADO, A. Prevalence and strain diversity of thermophilic campylobacters in cattle, sheep and swine farms. Journal of Applied Microbiology, Oxford, v. 103, n. 4, p. 977-984, 2007.

PAO, S.; HAGENS, B. E.; KIM, C.; WILDEUS, S.; ETTINGER, M. R.; WILSON, M. D.; WATTS, B. D.; WHITLEY, N. C.; PORTO-FETT, A. C. S.; SCHWARZ, J. G.; KASELOO, P.; REN, S.; LONG III, W.; LI, H.; LUCHANSKY, J. B. Prevalence and molecular analyses of Campylobacter jejuni and Salmonella spp. in cograzing small ruminants and wild-living birds. Livestock Science, Amsterdam, v. 160, n. 1, p. 163-171, 2014.

PAUlino, C. D.; SINGER, J. Análise de dados categorizados. São Paulo: Edgard Blucher, 2006.

PITKÄNEN, T. Review of Campylobacter spp. in drinking and environmental waters. Journal of Microbiological Methods, Amsterdam, v. 95, n. 1, p. 3947, 2013.

QUINLIVAN, T. D.; JOOP, A. J. A survey on the incidence and cause of ovine abortion in Hawkes Bay. New Zealand Veterinary Journal, Wellington, v. 30, n. 5, p. 65-68, 1982.

ROUG, A.; BYRNE, B. A.; CONRAD, P. A.; MILLER, W. A. Zoonotic fecal pathogens and antimicrobial resistance in county fair animals. Comparative Immunology, Microbiology and Infectious Diseases, Oxford, v. 36, n. 3, p. 303- 308, 2013.

SAHIN, O.; PLUMMER, P. J.; JORDAN, D. M.; SULAJ, K.; PEREIRA, S.; ROBBE-AUSTERMAN, S.; WANG, L.; YAEGER, M. J.; HOFFMAN, L. J.; ZHANG, Q. Emergence of a tetracycline-resistant Campylobacter jejuni clone associated with outbreaks of ovine abortion in the United States. Journal Clinical Microbiology, Washingnton, v. 46, n. 5, p. 1663-1671, 2008.

SALIHU, M. D.; JUNAIDU, A. U.; OBOEGBULEM, S. I.; EGWU, G. O. Prevalence and biotypes of campylobacter species isolated from Sheep in Sokoto State, Nigeria. International Journal of Animal and Veterinary Advances, Faisalabad, v. 1, n. 1, p. 6-9, 2009.

SCARCELLI, E.; GENOVEZ, M. E.; CARDOSO, M. V.; SOUZA, M. C. A. M.; GRASSO, L. M. P. S.; SOUZA, C. A. I.; TORRES, A. P. Avaliação do potencial de disseminação de Campylobacter spp por diferentes espécies animais. Arquivos do Instituto Biológico, São Paulo, v. 65, n. 1, p. 55-61, 1998.

SCARCELLI, E.; PIATTI, R. M.; CARDOSO, M. V. Detecção de agentes bacterianos pelas técnicas de isolamento e identificação e PCR-Multiplex em fetos bovinos abortados. Revista Brasileira de Reprodução Animal, Belo Horizonte, v. 28, n. 1, p. 23-27, 2004. 
SKIRROW, M. B. Diseases due to Campylobacter, Helicobacter and related bacteria. Journal of Comparative Pathology, Liverpol, v. 111, n. 2, p. 113-49, 1994.

SPROSTON, E. L.; OGDEN, I. D.; MACRAE, M.; FORBES, K. J.; DALLAS, J. F.; SHEPPARD, S. K.; CODY, A.; COLLES, F.; WILSON, M. J.; STRACHAN, N. J. Multi-locus sequence types of Campylobacter carried by flies and slugs acquired from local ruminant faeces. Journal of Applied Microbiology, Oxford, v. 109, n. 3, p. 829-838, 2010.

STANLEY, K. N.; WALLACE, J. S.; CURRIE, J. E.; DIGGLE, P. J.; JONES, K. Seasonal variation of thermophilic campylobacters in lambs at slaughter. Journal of Applied Microbiology, Oxford, v. 84, n. 6, p. 1111-1116, 1998.

STANSFIELD, D. G.; HUNT, B.; KEMBLE, P. R. Campylobacter gastroenteritis in fattening lambs. Veterinary Record, London, v. 118, n. 8, p. 210-211, 1986.
STEPHEN, L. W. Isolation, identification and subtyping of Campylobacter: where to from here? Journal of Microbiological Methods, Amsterdan, v. 95, n. 1, p. 3-7, 2013.

VARGAS, A. C.; CECIM, M.; VIANA, L. R.; SPRICIGO, D. A.; COSTA, M. M. Isolamento de Campylobacter jejuni em feto ovino abortado: relato de caso. Arquivos Brasileiros de Medicina Veterinária e Zootecnia, Belo Horizonte, v. 57, n. 3, p. 317-320, 2005.

WALT, M. L. Campylobacter jejuni infection. In: COETZER, J. A. W.; THOMSON, G. R.; TUSTIN, R. C. (Ed.). Infectious diseases of livestock with special reference to Southern Africa. Oxford: Oxford University Press, 1994. p. 1025-1029.

ZAN BAR, T.; YEHUDA, R.; HACHAM, T.; KRUPNIK, S.; BARTOOV, B. Influence of Campylobacter fetus subspecies fetus on ram sperm cell quality. Journal of Medical Microbiology, London, v. 57, n. 11, p. 14051410, 2008. 